\title{
Perlambatan Pertumbuhan dan Transisi Demografi di Indonesia
}

\author{
Fitri Rusdianasari $^{1}$, Siti Komariyah ${ }^{2 *}$, Moh. Adenan ${ }^{3}$ \\ 1,2,3 Fakultas Ekonomi dan Bisnis, Universitas Jember
}

\section{Informasi Artikel \\ Sejarah artikel: \\ Diterima Desember 2018 \\ Disetujui Januari 2019 \\ Dipublikasikan Maret 2019}

\section{Keywords:}

Growth Slowdowns,

Demographic Transition,

Demographic Bonus,

GDP per Capita

\begin{abstract}
A B S T R A C T
Macro economic fluctuation and Indonesian demographic symptom are the cause of the growth slowdowns. Global ecomomic downturn brings impact on domestic economi, both for developing country and developed country, as well as indonesia. Furthermore, the condition of indonesian demographic profile that tend to incrise is also affecting the slowing down for the economy. This research aims to find correlation beetwen macro economic and demographic variabel and their contribution for the economic slowdown, as well as to see the longrun relationship beetwen GDP percapita performance and demographic profile. In order to answer the question, a regression analysis is used. In addition, OLS method and cointegration test by using johantion test is applied. Result of the estimation shows that demographioc variabel is causing Indonesian economic slowdowns. However, other Indonesian demographic profiles such as dependency ratio and life expectation, in the longrun, positively contributed to Indonesia economy. This result supports the indonesia demographic projection that explain whithin year 2020-2030 indoonesia will enjoy demographic bonus in which give great contrib tion for the Indonesian economy.
\end{abstract}




\section{PENDAHULUAN}

Perlambatan pertumbuhan baru baru ini muncul sebagai akibat dari ketidakpastian perekonomian dunia. Perlambatan perekonomian Indonesia ini ditandai dengan menurunnya kinerja pertumbuhan pada kuartal II pada tahun 2015 dengan tingkat pertumbuhan sebesar $4,67 \%$ (Fithria dan Hastiadi, 2015). Angka ini lebih rendah dibandingkan dengan 2015 kuartal I yang mencapai angka 4,72\%. Fenomena ini muncul sebagai dampak dari merosotnya perekonomian negara-negara besar yang menjadi mitra dagang Indonesia seperti perlambatan perekonomian China dan Amerika Serikat beberapa periode terakhir ini. Kondisi tersebut melatarbelakangi munculnya berbagai kebijakan untuk menciptakan pertumbuhan baru yang dapat membentuk dan mendorong pertumbuhan ekonomi suatu negara.

Beberapa instrumen perekonomian global yang memberikan pengaruh terhadap kinerja pertumbuhan ekonomi pada negara dengan sistem ekonomi terbuka seperti Indonesia antara lain kinerja perdagangan, investasi, industri, jasa serta kinerja nilai tukar. Dalam menanggapi hal tersebut, Indonesia juga telah melakukan berbagai pengkajian kebijakan untuk upaya meningkatkan pencapaian pada kondisi ekonomi dan sosial. Berbagai kebijakan telah diarahkan menuju penguatan pasar terlebih pada sektor produksi serta penguatan ikim usaha melalui investasi (OECD Indonesia, 2016).

Disisi lain, perbedaan permasalahan yang terjadi dalam lingkup internal juga berkontribusi dalam kinerja perekonomian Indonesia seperti masalah kependudukan yang muncul secara natural dan tidak dapat dihindari. Tercatat Indonesia merupakan negara dengan jumlah penduduk terbesar keempat dunia setelah China (Thiongkok), India dan Amerika Serikat dengan total jumlah populasi penduduk sebesar 263 juta jiwa pada tahun 2017 (Worldbank, 2017). Kondisi ini dapat memberikan kontribusi positif ketika negara mampu mengelola bonus demografi dengan baik dan sebaliknya akan menjadi bomerang ketika manajemen kependudukan tidak dapat dilakukan secara optimal. Ini menunjukkan bahwa kekuatan demografi Indonesia sebenarnya dapat menjadi kontribusi bagi percepatan pertumbuhan ekonomi. Namun persebaran komposisi penduduk yang tidak merata ternyata memunculkan dua sisi dampak yang berbeda. Idealnya, bonus demografi dapat berkontribusi dalam pembangunan dan percepatan pertumbuhan jika dapat dikelola dengan baik dan maksimal.

Dinamika penduduk memiliki kontribusi besar dalam memengaruhi kinerja GDP per kapita dan pertumbuhan ekonomi. Hal ini menjadi penting untuk dibahas mengingat peran manusia dalam menciptakan pertumbuhan sangat dominan. Bermula dari teori kependudukan Robert Malthus yang memaparkan bahwa profil penduduk memiliki peran penting dalam menciptakan pertumbuhan. Transisi demografi menjadi sangat penting untuk membangun perekonomian masa depan dan mendukung percepatan pertumbuhan suatu negara (Jayaasoriya, 2017). Studi empiris Aiyar dan Mody (2011) menemukan bahwa perubahan dalam struktur usia bersama dengan partisipasi partisipasi tenaga kerja yang lebih tinggi untuk percepatan pertumbuhan. Bloom dan Williamson (1998) secara khusus mengaitkan kondisi Asia Timur terutama untuk keberhasilan transisi dan rekonstruksi dari bonus demografi bersama dengan kekuaatan perdagangan menjadi alasan utama percepatan ekonomi. Namun dinamika demografi yang cepat mampu menahan pertumbuhan ekonomi suatu negara. Bloom dan Williamson (1998) menunjukkan hasil bhawa reformasi demografi dalam suatu pertumbuhan dapat mendorong kemajuan negara negara Asia dan menyumbang dividen banyak bagi negara mereka.

Beberapa studi empiris yang fokus 
pada fenomena perlambatan perekonomian dilakukan oleh Pritchett's (2000) and Hausmann, et al. (2005). Studi keduanya menyoroti tentang faktor yang mempercepat dan memperlambat pertumbuhan ekonomi suatu negara secara berkelanjutan. Hasil analisisnya menyatakan bawah perlambatan pertumbuhan menunjukkan korelasi antara investasi, kinerja perdagangan serta depresiasi nilai tukar riil. Selain itu studi Eichengreen, et al. (2011) dengan membangun sampel pada perekonomian yang tumbuh cepat melambat secara signifikan dapat teridentifikasi ketika pendapatan per kapitanya mencapai sekitar US \$ 17000 pada tahun 2005 dengan kondisi perdagangan internasional diasumsikan konstan.

Studi yang berbeda dilakukan oleh Jayasooriya, (2017) yang menyoroti tiga domain penelitian meliputi kesenjangan pendapatan menengah kebawah, perlambatan pertumbuhan dan demografi di Asia Selatan. Studi ini memainkan 3 permodelan sesuai domain penelitian yaitu ksenjangan pendapatan, perlambatan perekonomi dan demografi. Untuk melihat faktor penentu atau penyabab perlambatan pertumbuhan ekonomi diidentifikasi pada hasil analisis yang menunjukkan hasil negatif signifikan
(Jayasooriya, 2017). Pada model perlambatan perekonomian juga diintegrasikan komponen demografi untuk melihat kontribusi dalam memengaruhi perlembatan perekonomian di Asia Selatan. Hasil analisis studi empiris ini menunjukkan bahwa perlambatan perekonomian dipengaruhi oleh instrumen makoekonomi dan demografi yang tidak stabil.

Fenomena dari permasalahan yang memicu perlambatan perekonomian dan pembangunan ini dapat disoroti dari fluktuasi data makroekonomi dan pertumbuhan ekonomi yang dapat dilihat dari kinerja GDP per kapita.

Kondisi makroekonomi Indonesia dapat dilihat pergerakannya pada Gambar 1 yang menunjukkan fluktuasi GDP per kapita, import dan ekspor yang bersumber dari permasalahan eksternal. Terlihat bahwa kinerja ekspor dan impor tidak diikuti oleh pergerakan pertumbuhan GDP. Ini menunjukkan bahwa aktifitas luar negeri seperti ekspor dan impor tidak direspon signifikan oleh GDP sehingga tidak memberikan kontribusi yang dominan pada kinerja ekonomi Indonesia. Sementara itu pada periode 2010-2012 terlihat pergerakan ekspor dan impor yang cenderung meningkat, namun justru GDP bergerak

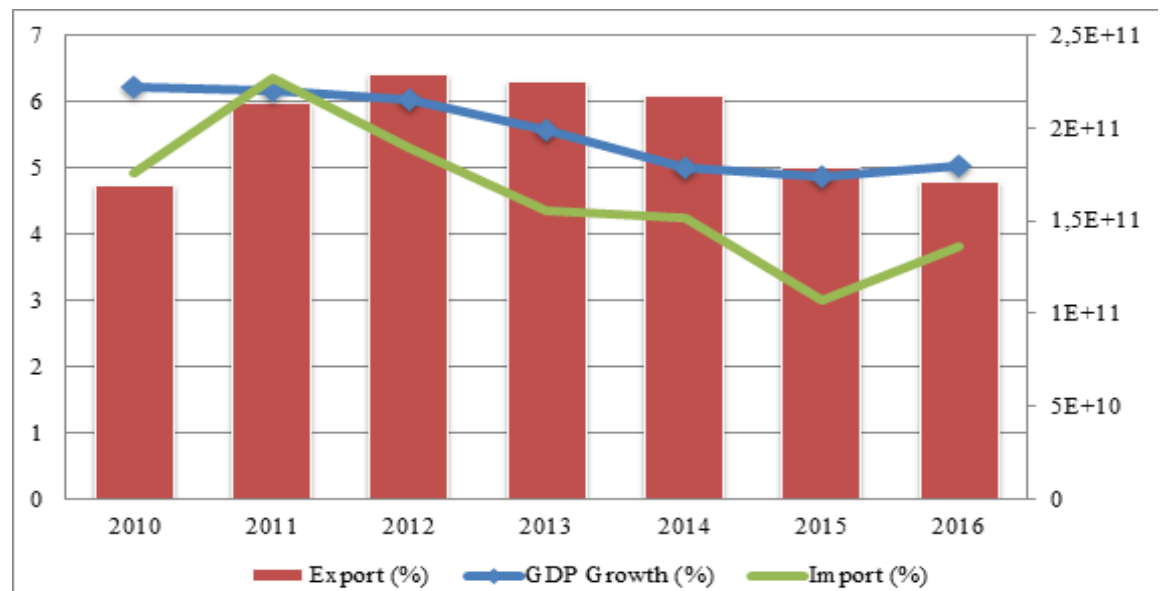

Gambar 1. Fluktuasi Variabel Makroekonomi Indonesia

Sumber: Worldbank, 2018 
menurun hingga periode 2014 yang selanjutnya mengalami kenaikan secara perlahan ditahun 2016. Disisi lain dapat dilihat bahwa pergerakan impor cenderung lebih berfluktuatif pada periode 2011 hingga 2016. Hal ini menujukkan bahwa kinerja perdagangan Indonesia belum mencapaii kestabilan optimal sehingga GDP sebagai tolak ukur peerekonomian belum mampu merespon dengan baik. signifikan. Sementara komponen pertumbuhan melalui GDP per kapita cenderung mengalami fluktuasi yang tinggi terlebih pada tahun 2015 yang menunjukkan angka hingga 3334,5491 U\$. Penurunan tersebut bukan karena penurunan demografi Indonesia, melainkan akibat dari melemahnya pertumbuhan investasi dan ekspor Indonesia pada 2015 (Worldbank, 2015).

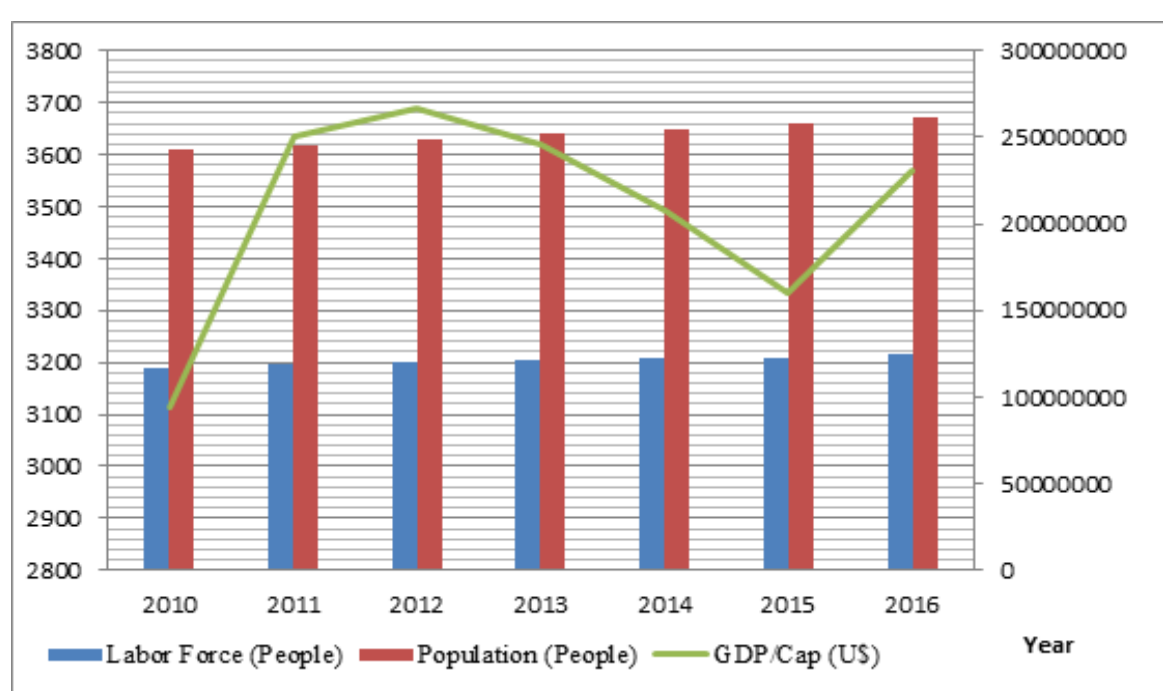

Gambar 2. Demografi dan GDP per kapita Indonesia

Sumber: Worldbank, 2018

Pertumbuhan penduduk yang rendah di negara-negara berpenghasilan tinggi cenderung menciptakan masalah sosial dan ekonomi sementara pertumbuhan penduduk yang tinggi di negara-negara berpenghasilan rendah dapat memperlambat perkembangan pembangunan dan pertumbuhan ekonomi (Peterson, 2017). Kondisi ini menjadi titik dimana negara berkembang seperti Indonesia dengan jumlah penduduk yang tinggi dapat mengarahkan pembangunan melalui optimalisasi bonus demografinya. Gambar 2 menunjukkan pergerekan populasi dan angkatan kerja di Indonesia dengan GDP per kapita dalam satuan dollar. Terlihat pada Gambar 2 bahwa komponen demografi Indonesia cenderung meningkat meskipun tidak pernah mengalami peningkatan yang terlalu
Secara global, perlambatan ekonomi Indonesia didorong oleh faktor eksternal dan internal seperti perlambatan perekonomian luar negeri dan kinerja ekspor. Namun, dalam konteks internal, perananan demografi sebagai instrumen penting dalam pembangunan juga perlu disoroti lebih jauh. Profil demografi seperti angka kelahiran, angka kematian serta angka ketergantungan juga dapat berkontribusi pada pembangunan dan pertumbuhan dalam jangka panjang (Nuno, et al. 2012). Penelitian ini bertujuan untuk melihat faktor penyebab perlambatan ekonomi yang dilihat dari komponen makroekonomi dan demografi. Selain itu, penelitian ini juga bertujuan untuk melihat hubungan jangka panjang dan hubungan saling keterkaitan (kausali) antara variabel demografi dan 
pertumbuhan ekonomi Indonesia (GDP per kapita). Pada konsepnya, penelitian ini lebih menekankan pada faktor-faktor penentu perlambatan pertumbuhan ekonomi serta profil demografi Indonesia yang dapat mendorong pertumbuhan Indonesia.

\section{LANDASAN TEORI}

Pendekatan perlambatan dari penelitian ini mengikuti perlambatan pertumbuhan dan kerangka teori Neoklasik yang cenderung menguji faktor penentu penurunan seperti makro ekonomi, demografi, perdagangan, dan sumber daya manusia untuk merekomendasikan kebijakan. Studi utama yang mewakili penelitian adalah Eichengreen, et al. (2011, 2013) dan Robertson dan Ye (2013). Pendekatan perlambatan pertumbuhan ditujukan untuk melibatkan pertumbuhan ekonomi model Neoklasik dengan perlambatan pada periode tertentu. Seperti beberapa literature menyebutkan Sollow merupakan ssalah satu pelopor Neoklasik sehingga studi empiris Aiyar et al. (2013) mengikuti model pertumbuhan Solow menggunakan prediksi teorinya. Penelitiannya mengidentifikasi perlambatan pertumbuhan menggunakan riteria perbedaan antara pertumbuhan aktual dan potensial. Model Solow-Swan memprediksi bahwa tingkat pendapatan ekonomi yang rendah akan bertemu dalam waktu tertentu dengan pendapatan negara-negara kaya, karena keduanya harus memiliki tingkat tabungan yang sama untuk modal manusia dan fisik.

Hal berbeda ditunjukkan oleh Hausmann, et al (2005) yang mengklasifikasikan percepatan pertumbuhan menggunakan tiga kriteria da menggunakan variabel dummy sebagai variabel dependennya yang disebut dengan model probit seperti halnya studi Jayasooriya (2017). Studi menggunakan model probit untuk menghubungkan perlambatan pertumbuhan dengan beberapa variabel yang digunakan sebagai faktor penentu. Model Solow mengurangi pertumbuhan ekonomi hingga ke akumulasi modal, tenaga kerja, dan pertumbuhan produktivitas, memprediksi tingkat konvergensi pendapatan jangka panjang $2 \%$, yang menyiratkan bahwa ekonomi bergerak ke kondisi mapan dalam sekitar 70 tahun (Mankiw, Romer, dan Weil 1992). Pendepatan ini dapat digunakan untuk melihat dan memprediksi kapan perekonomian akan mengalami penurunan atau perlambatan.

Ekonomi Neoklasik dibangun atas dasar penurunan konsep konsep sehingga diperoleh berbagai turunan konsep akurat yang dapat mengidentifikasi konvergensi ekonomi dengan baik (Rynn, 2001). Robert Solow muncul pada 1956 dengan mengkritik model Harrod-Domar yang mengidentifikasi asumsi proporsi tetap tenaga kerja dan modal sebagai penyebab keseimbangan pertumbuhan yang pada kenyataannya menyeimbangkan keduanya. Model Solow berfokus pada ekonomi tertutup di mana output $Q$ dihasilkan oleh faktor tenaga kerja (L0 dan modal (K) dengan skala produksi konstan. Romer (1996) menafsirkan asumsi pengembalian konstan untuk menyiratkan bahwa ekonomi di bawah pertimbangannya cukup besar sehingga keuntungannya akan turun.

Negera golongan Emerging market economies (EMEs) telah menjadi penggerak pertumbuhan global yang signifikan dan permintaan eksternal kawasan euro pada abad ke-21. Namun, sejak 2010 pertumbuhan EME telah mengalami tren penurunan. Sebagian dari moderasi itu didorong oleh faktor struktural seperti berkurangnya akumulasi modal dan peningkatan produktivitas serta berkurangnya integrasi perdagangan global. Selain itu, masalah yang timbul terkait dengan perlambatan perekonomian pada negara negara maju pasca gejolak ekonomi global (ECB Economic Bulletin, 2016). Penurunan harga komoditas ekspor secara global memberikan dampak yang meluas terhadap harga secara umum serta terjadi pengetatan terhadap kondisi keuangan global sejak 2013 
lalu. Ini mengindikasikan bahwa gejolak ekonomi global dan kemerosotan kinerja ekonomi negara EMEs memberikan kontribusi besar dalam perlambatan ekonomi Indonesia. Faktor eksternal juga berkontribusi pada perlambatan dalam EME. Literatur telah menyoroti dampak bahwa faktor eksternal, seperti dinamika perdagangan global, lingkungan pembiayaan global dan fluktuasi pasar komoditas, memiliki kegiatan ekonomi EME. faktor eksternal telah menyumbang sekitar setengah dari semua variasi dalam dinamika pertumbuhan dalam dua dekade terakhir. Melihat periode terbaru, faktor eksternal penting dalam penurunan awal yang diamati pada 2010.

Berangkat dari teori Sollow sebagai peleopor pendekatan Neoklasik, maka peran modal manusia yang mangarah pada jumlah tenaga kerja juga berperan dominan dalam menciptakan pertumbuhan ekonomi. Seiring teori tersebut, Indonesia sebagai negara dengan jumlah penduduk tinggi hingga menjapai 263 juta jiwa sehingga dimungkian memiliki bonus demografi seperti tercatat pada data bank dunia yang menunjukkan angka sebesar 125 juta jiwa hampir sebagian dari jumlah penduduk Indonesia pada akhir taun 2016 lalu. Ini menunjukkan bahwa bonus demografi Indonesia akan membantu percepatan perekonomian Indonesia jika dapat dimanajemen dengan optimal keberadaannya, namun hasil akan berbalik ketika manajemen manusia tidak dilakukan secara optimal. Istilah demografi dalam model pertumbuhan baru dikenal dengan transisi demografi yang diartikan sebagai perubahan struktur demografi yang menunjukkan angka mortalitas (kematian) menurun sementara untuk angka fertilitas (kelahiran) semakin meningkat meskipun peningkatan tersebut hanya terjadi pada moment tertentu (Lehmijoki, 2003). Transisi demografi ini akan menciptakan bonus demografi setelah penduduk berada pada posisi usia produktif sehingga dapat me- micu peningkatan produktifitas yang akan mendorong output agregat dan megarah pada peningkatan pertumbuhan.

Studi empiris Pritchett's (2000) and Hausmann, et al. (2005) menyoroti tentang perlambatan ekonomi yang disebabkan oleh gejolak makroekonomi global dan domestik, sementara itu Jayasooriya (2017) menggabungkan dua komponen yang menyoroti perlambatan ekonomi yaitu terkait dengan kinerja makroekonomi dan profil demografi domestik. Beberapa studi empiris terkait transisi demografi yang terjadi dibeberapa negara menyiratkan hubungannya dengan pertumbuhan ekonomi suatu negara. Penelitian Jayasooriya, (2017) menunjukkan hasil bahwa bebrapa variabel profil demografi memberikan pengaruh negatif terhadap pertumbuhan ekonomi sehingga pertumbuhan ekonomi mengalami perlambatan pada negara berpenghasilan menengah. Variabel demografi yang dominan berpengaruh negatif terhadap pertumbuhan ekonomi yaitu harapan hidup. Ini menunjukkan bahwa harapan hidup yang rendah akan memengaruhi perlambatan pertumbuhan karena dapat memunculkan masalah sosial ekonomi baru. Studi empiris lain dilakukan oleh Nuno, et al. (2012) yang memilih menyoroti demografi pada negara-negara maju dengan pendapatan tinggi. Hasil analisisnya menunjukkan hal yang sama bahwa variabel profil demografi yakni angka beban ketergantungan dalam jangka panjang memberikan pengaruh pada perlambatan ekonomi di Jepang, Perancis, Jerman, Italia dan Spanyol. Sementara itu, studi empiris Mason, et al. (2008) yang melakukan penelitian di Pasifik menunjukkan hasil bahwa penurunan kematian, peningkatan beban ketergantung dan peningkatan usia lanjut dalam jangka panjang akan menurunkan pendapatan per kapita serta tabungan agregat. Hal ini mengindikasikan bahwa selain dari sisi kebijakan makro, dari sisi demografi sendiri harus ada pengendalian dan manajemen resiko untuk meminimalisir hal tersebut. 
Perbedaan pendapat tentang peran bonus demografi yang berhubungan dengan pembangunan ekonomi sering mengalami perdebatan dalam lingkup akademisi China. Dalam penelitian Fang (2000) mencoba mengungkap hubungan transisi demografi dengan pembangunan ekonomi dari dua sisi yang berbeda. Berdasarkan bukti empiris dinamika populasi bahwa terjadi defisit dividen dari keberadaan demografi di China. Sehingga penelitian ini mengusulkan beberapa langkah-langkah untuk mengeksploitasi potensi dari bonus demografi pertama, menciptakan kondisi untuk demografi serta mencari sumber pertumbuhan ekonomi (Fang, 2000).

Pada beberapa literature nexus antara pengembangan populasi lebih fokus dibahas hubungannya dengan tingkat pertumbuhan ekonomi. Transisi demografi yang didalami terkait dengan jumlah populasi, tingkat kelahiran dan tingkat kematian, tetapi tidak terkait erat dengan pertumbuhan ekonomi. Muara utama yang dituju mengarah pada arus pertumbuhan dan menggabungkan populasi dalam pertumbuhan endogen. Perubahan angkatan kerja dan penurunan kesuburan akan meningkatkan bonus (Williamson, 1997).

\section{METODOLOGI PENELITIAN}

Data penelitian ini diperoleh dari Worldbank berbentuk data time series dengan series mulai dari tahun 1980-2016. Pengambilan data dilatarbelakangi oleh fenomena perambatan ekonomi Indonesia dan peningkatan populasi Indonesia yang semakin tahun semakin meningkat diiringi dengan kenaikan profil demografi lainnya seperti tingkat fertilitas, tingkat mortalitas dan angka beban ketergantungan. Berdasarkan hal tersebut dapat dipotret dua permasalahan yaitu perlambatan ekonomi yang dapat disebabkan karena kinerja makroekonomi domestik dan global serta kondisi demografi Indonesia yang dapat berdampak pada pertumbuhan.

Berdasarkan permaslahan diatas, maka digunakan analisis regresi dengan metode Ordinary Least Square (OLS) untuk melihat faktor yang menyebabkan perlambatan ekonomi Indonesia yang diproksi dari GDP per kapita. Data yang digunakan untuk melihat faktor penyebab perlambatan ekonomi antara lain data makroekonomi dan demografi Indonesia yang terdiri dari pertumbuhan GDP, lag GDP, ekspor, impor, persebaran industri secara makro, angkatan kerja dan jumlah populasi Indonesia. Kemudian untuk melihat kontribusi variabel profil demografi secara lengkap serta hubungan jangka panjangnya dalam memengaruhi pertumbuhan ekonomi Indonesia melaui kinerja GDP per kapita dengan uji granger causality dan uji kointegrasi. Variabel yang digunakan antara lain tingkat fertilitas, tingkat mortalitas, dependency ratio, life expectation, jumlah angkatan kerja dan jumlah populasi Indonesia.

Metode OLS merupakan metode yang memilki alat analisis yang kuat dan terkenal dalam metode analisis regresi. (Gujarati, 2004: 55). Pada dasarnya OLS merupakan metode regresi yang digunakan untuk permasalahan sederhana seperti mencari pengaruh antara variabel dependen dan variabel independen dalam suatu model (Greene, 2012). Ordinary Least Squares (OLS) regression adalah teknik pemodelan linear umum yang dapat digunakan untuk memodelkan satu variabel respon yang telah direkam pada skala intervalnya (Hutcheson, 2011). Untuk melihat hubungan jangka panjang pada permodelan demografi dan pertumbuhan ekonomi digunakan uji kointegrasi. Selain itu juga dilakukan uji kausaitas granger untuk melihat hubungan korelasi antara variabel demografi dan GDP per kapita. Pada pengujian kointegrasi persyaratan utama dalam permodelan bahwa data yang digunakan memiliki kestasioneran untuk tujuan relevansi pada limitasi (Hjalmarsson and Österholm, 2007). Selain untuk mengetahui hubungan jangka panjang pada model, 
uji kointegrasi juga untuk melihat derajat integrasi yang sama antar variabel penelitian. Variabel disebut terkointegrasi jika tidak mengandung unit root pada error term sementara jika variabel mengandung trend yang tidak berbeda jauh dengan variabel yang lain, maka variabel tersebut memiliki hubungan jangka panjang (Mencet, et al. 2006 dan Sorensen, 2005). Ketika variabel terdapat kintegrasi maka variabel tersebut mampu memberikan kecenderungan umum pada data yang digunakan (AbuBader dan Abu Qarn, 2007). Selanjutnya untuk melihat korelasi antar variabel dilakukan pengujian granger causality yang merupakan salah satu serangkaian pengujian pada vector autoregresive.

Dalam penelitian ini terdapat dua model yang digunakan sesuai dengan permasalahan yang diteliti. Pertama, permodelan difokuskan untuk melihat faktor penentu terjadinya perlambatan ekonomi. Kedua, permodelan yang difokuskan pada hubungan jangka panjang antara variabel demografi dengan GDP per kapita. Permodelan diadopsi dari penelitian Jayasooriya (2017) sebagai berikut:

Model untuk melihat perlambatan ekonomi Indonesia (OLS):

$$
\begin{aligned}
& \frac{G D P}{\text { Cap }_{t}}=G D P \text { Growth }_{t}, \text { Export }_{t}, \text { Import }_{t}, \\
& \text { Industry Share }_{t}, \text { LaborForce }_{t}, \text { Population }_{t}
\end{aligned}
$$

Model untuk melihat hubungan jangka panjang dan korelasi variabel demografi dan pertumbuhan ekonomi Indonesia sebagai berikut:

$$
\frac{G D P}{C a p_{t}}=F R_{t}, M R_{t}, L F_{t}, P o p_{t}, D R_{t}, L E_{t}
$$

dimana GDP/Cap adalah pendapaan per kapita (U\$), FR adalah fertility rate (\%), MR adalah mortality rate (\%), LF adalah angkatan kerja (Juta Jiwa), Pop adalah populasi Penduduk (Juta Jiwa), DR adalah Rasio Beban Ketergantungan (\%), LE adalah
Angka Harapan Hidup (\%), t adalah series

Permodelan diatas kemudian diturunkan berdasarkan model estimasi sebagai berikut:

Model untuk melihat perlambatan ekonomi Indonesia:

$$
\frac{G D P}{\text { Cap }_{t}}=G D P \text { Growth }_{t}+\text { Export }_{t}+\text { Import }_{t}+
$$

Industry Share $_{t}+$ LaborForce $_{t}+$ Population $_{t}+e_{t}$

Model untuk melihat hubungan jangka panjang dan korelasi variabel demografi dan pertumbuhan ekonomi Indonesia sebagai berikut:

$\frac{G D P}{C a p_{t}}=F R_{t}+M R_{t}+L F_{t}+P o p_{t}+D R_{t},+L E_{t}+e_{t}$

\section{HASIL DAN PEMBAHASAN}

Penelitian ini terdapat dua permodelan yang bertujuan untuk melihat faktor yang menyebabkan perlambatan pertumbuhan ekonomi dengan menggunakan variabel makroekonomi dan demografi serta untuk melihat hubungan jangka panjang dan korelasi pada variabel demografi dengan pertumbuhan ekonomi Indonesia. Langkah pertama yang dilakukan sebelum mengestimasi model dilakukan uji stasioneritas data untuk mengetahui distribusi data pada model yang disebut dengan uji akar unit.

Hasil Tabel 1 memperlihatkan uji stasioneritas data pada masing-masing variabel yang digunakan dalam penelitian. Terlihat bahwa masing-masing variabel stasioner pada tingkat masing-masing. Variabel makroekonomi yang terdiri dari GDP growth dan GDP lag stasioner pada tingkat level dengan angka 0,0009 pada masing-masing variabel. Sementara variabel GDP per kapita, ekspor, impor, dan industry share stasioner pada tingkat first difference sehingga data harus diturunkan 
Tabel 1

Uji Stasionaritas

\begin{tabular}{cccc}
\hline Variable & Stasionarity Test & Variable & Stasionarity Test \\
\hline GDP/Cap & $0,0036^{* *}$ & Labor Force & $0,0083^{* *}$ \\
GDP Growth & $0,0009^{*}$ & Population & $0,0649^{* *}$ \\
GDP Growth Lag & $0,0009^{*}$ & Mortality Rate & 0,0007 \\
Import & $0,0000^{* *}$ & Fertility Rate & $0,0092^{* *}$ \\
Export & $0,0004^{* *}$ & Life Expected & 0,0108 \\
Industry Share & $0,0000^{* *}$ & Dependency Ratio & 0,0317 \\
\hline
\end{tabular}

Note:

$\left({ }^{*}\right)$ level; $\left({ }^{* *}\right)$ first difference; $\left({ }^{* * *}\right)$ second difference

Sumber: Data Diolah, 2018

sesuai dengan stasioneritasnya. Sementara variabel demografi juga menunjukkan hasil stasioner yang berbeda pada masing masing variabel. Terlihat bahwa angkatan kerja dan tingkat fertilitas stasioner pada tingkat level, sementara life expected dan dependency ratio stasioner pada tingkat level. Pada variabel populasi menunjukkan hasil bahwa data stasioner pada tingkat second difference. Sehingga dari hasil tersebut dapat disimpulkan bahwa semua data yang digunakan pada masing-masing variabel memiliki stasioneritas data yang bervariasi.

Estimasi pada permodelan pertama yang bertujuan untuk melihat faktor penyebab perlambatan pertumbuhan Indonesia dapat dilihat dari hasil estimasi OLS. Untuk melihat faktor penentu perlambatan dapat diketahui dari nilai probabilitas dan nilai koefisien pada variabel makroekonomi dan demografi. Jika nilai probabilitas kurang dari nilai alfa 5\% dan $10 \%$ dan nilai koefisien negatif maka variabel tersebut dikatakan menjadi faktor penentu perlambatan ekonomi Indonesia dan sebaliknya. Jika variabel tersebut berpengaruh signifikan dan memiliki nilai koefisien positif maka variabel tersebut dapat mendorong perekonomian Indonesia. Hasil estimasi OLS dapat dilhat pada Tabel 2.

Hasil estimasi OLS pada model perlambatan ekonomi Indonesia yang mengintegrasikan variabel makroekonomi dan demografi dapat dilihat pada Tabel 2 . Hasil analisis menunjukkan bahwa variabel demografi yang menjadi faktor penentu perlambatan ekonomi Indonesia. Kondisi ini dapat dilihat dari nilai koefisien dan probabilitas pada estimasi OLS. Terlihat bahwa variabel labor force memiliki nilai koefisien negatif sebesar -6,2005 dan nilai probabilitas sebesar 0,0541 kurang dari nilai alfa 5\%. Ini berarti bahwa ketika terjadi kenaikan angkatan kerja sebesar 6,2005 maka justru menurunkan atau memperlambat pertumbuhan ekonomi yang diproksi dengan GDP per kapita sebesar

Tabel 2

Hasil Estimasi OLS Pada Model Perlambatan Ekonomi

\begin{tabular}{ccc}
\hline Variable & Coeficient & Probability \\
\hline Gdpgrowth & 20.72563 & 0.1001 \\
Gdplag & 9.111339 & 0.1840 \\
Deksport & $7.52 \mathrm{E}-09$ & 0.0000 \\
Dimport & $4.70 \mathrm{E}-09$ & 0.5845 \\
Dindustryshare & $6.85 \mathrm{E}-05$ & 0.0641 \\
Dlaborforce & $-6.20 \mathrm{E}-05$ & 0.0541 \\
Dpopulation & -0.000254 & 0.0730 \\
\hline
\end{tabular}

Sumber: Data Diolah, 2018 
nilai koefisien tersebut. Hal sama ditunjukkan oleh variabel demografi lain yang menunjukkan bahwa jumlah penduduk (populasi) ternyata menjadi faktor penyebab melambatnya pertumbuhan ekonomi Indonesia. Hal ini dikonfirmasi dengan nilai koefisien sebesar $-0,000254$ dan nilai probabilitas sebesar 0,0730 lebih kecil dari nilai alfa $5 \%$. Ini berarti ketika terjadi kenaikan jumlah penduduk sebesar 0,00254 akan menurunkan atau memperlambat perekonomian sebesar nilai koefisien.

Sementara itu, hasil analisis juga menunjukkan bahwa variabel makroekonomi ekspor dan share industri ternyata justru memberikan kontribusi positif terhadap pertumbuhan ekonomi Indonesia. Kondisi ini ditunjukkan dengan nilai koefisien positif dan nilai probabilitas lebih kecil dari nilai alfa pada kedua variabel. Pada variabel ekspor terlihat nilai koefisien sebesar 7,5209 dan nilai probabilitas sebesar 0,0000. Ini menunjukkan bahwa ketikan terjadi kenaikan ekspor sebesar 7,5209 akan meningkatkan pertumbuhan ekonomi Indonesia melalui GDP per kapita sebesar nilai tersebut. Hal yang serupa ditunjukkan oleh persebaran industri di Indonesia yang menunjukkan nilai koefisien 6,8505 dan nilai probabilitas sebesar 0,0641 . Hasil ini berarti bahwa ketika terjadi kenaikan jumlah persebaran industri, ini akan meningkatkan pertumbuhan ekonomi sebesar nilai koefisien tersebut. Sementara variabel laju pertumbuhan ekonomi, lag pertumbuhan ekonomi serta impor belum memberikan kontribusi signifikan terhadap perlambatan akan peningkatan pertumbuhan ekononomi Indonesia selama periode penelitian ini.

Tabel 3

Uji Johansen

\begin{tabular}{ccccc}
\hline $\begin{array}{c}\text { Hypothesized } \\
\text { No. of CE(s) }\end{array}$ & Eigenvalue & $\begin{array}{c}\text { Trace } \\
\text { Statistic }\end{array}$ & $\begin{array}{c}\mathbf{0 . 0 5} \\
\text { Critical Value }\end{array}$ & Prob. $^{* *}$ \\
\hline None $^{*}$ & 0.952123 & 242.8622 & 125.6154 & 0.0000 \\
\hline
\end{tabular}

Sumber: Data Diolah, 2018
Pada model kedua yang memfokuskan untuk melihat hubungan jangka panjang antara variabel demografi dan pertumbuhan ekonomi, dilakukan uji kointegrasi dengan metode Johansen test. Pengujian ini untuk melihat apakah terdapat hubungan jangka panjang antara variabel demografi yang terdiri dari profil demografi antara lain tingkat kelahiran, tingkat kematian, dependency ratio, life expected, labor force dan jumlah populasi Indonesia dengan pertubuhan ekonomi. Untuk melihat apakah terdapat hubungan jangka panjang atau tidak dapat diketahui dari perbandingan antara trace statistic value dan critical value. Jika trace statistic value lebih besar dari critical value maka model tersebut terindikasi memiliki hubungan jangka panjang. Namun, ketika trace statistic value lebih kecil dari critical value maka model tersebut tidak terindikasi memiliki hubungan jangka panjang. Hasil uji kointegrasi ditunjukkan pada Tabel 3.

Hasil uji Johansen terlihat pada Tabel 3 yang menunjukkan bahwa terdapat hubungan jangka panjang yang signifikan pada model 2 yakni antara variabel demografi dan pertumbuhan ekonomi Indonesia. Hasil tersebut dapat terlihat dari perbandingan trace statistic value dan critical value dimana nilai trace statistic lebih besar dibandingkan dengan critical value yang dikonfirmasi dengan angka 242,8622 $>$ 125,6154. Hubungan jangka panjang tersebut berpengaruh singifikan yang dikonfirmasi dengan nilai probabilitas pada Johansen test sebesat $0,0000<$ nilai alfa $5 \%$. 
Sementara itu untuk melihat korelasi pada model kedua meliputi variabel profil demografi dengan pertumbuhan ekonomi dilakukan uji kasulitas granger sehingga dapat diketahui pada masingmasing variabel hubungan korelasi atau saling keterkaitannya. Untuk melihat variabel tersebut memiliki korelasi atau tidak dapat dilihat pada nilai probabilitas pada masing-masing variabel dengan variabel lain. Jika nilai probabilitas kurang dari nilai alfa hanya pada satu variabel maka terdapat korelasi satu arah, namun jika terdapat pada kedua variabel maka terdapat dua arah hubungan korelasi. Hasil uji korelasi dengan kausalitas granger ini dapat dipaparkan pada Tabel 4. jadi pada sesama variabel profil demografi yang ditunjukkan dengan nilai probabilitas kurang dari nilai alfa $5 \%$ dan $10 \%$. Terlihat bahwa angka beban ketergantung memiliki hubungan dua arah atau terjadi korelasi dengan jumlah penduduk Indonesia dengan nilai probabilitas 0,0065 dan 0,0959 kurang dari nilai alfa $5 \%$ dan $10 \%$. Selain itu juga variabel life expected memilikki hubungan korelasi dengan jumlah penduduk Indonesia yang ditunjukkan dengan nilai probabilitas kurang dari nilai alfa 5\% dan $10 \%$ yakni 0,0012 dan 0,0716 . Selanjutnya, variabel yang teridentifikasi memiliki hubungan kausalitas yakni variabel life expected dengan tingkat kelahiran dengan nilai probabilitas 0,0960 dan 0,0987.

Tabel 4

Kausalitas Granger untuk Profil Demografi dan Pertumbuhan

\begin{tabular}{ccc}
\hline Variabel & Probabilitas & Keterangan \\
\hline DR dan Population & 0,0065 & Terdapat Kausalitas \\
Population dan DR & 0,0959 & Terdapat Kausalitas \\
LE dan Population & 0,0012 & Terdapat Kausalitas \\
Population dan LE & 0,0716 & Terdapat Kausalitas \\
LE dan Fertility & 0,0960 & Terdapat Kausalitas \\
Fertility dan LE & 0,0987 & Terdapat Kausalitas \\
\hline
\end{tabular}

Note: DR= Dependency Ratio; LE= Life Expected

Sumber: Data Diolah, 2018

Tabel 5

Estimasi Model Profil Demografi

\begin{tabular}{ccc}
\hline Variable & Coefficient & Probability \\
\hline Dfertility & -890.5460 & 0.8564 \\
Mortality & -5.292481 & 0.9245 \\
Dlaborforce & $6.22 \mathrm{E}-05$ & 0.4673 \\
Dpopulation & 0.000771 & 0.4157 \\
Agedependency & -524.2462 & 0.0017 \\
Lifeexpectacy & 2172.857 & 0.0002 \\
\hline
\end{tabular}

Sumber: Data Diolah, 2018

Hasil kausalitas granger dapat dilihat pada pemaparan di Tabel 4. Hasil menunjukkan bahwa kausalitas hanya ter-
Sementara variabel lainnya tidak terindikasi memiliki hubungan kausalitas. Estimasi pada model kedua yang menunjukan kon- 
tribusi variabel profil demografi terhadap GDP per kapita Indonesia yang mewakili pertumbuhan ekonomi terlihat pada Tabel 5 .

Hasil estimasi pada Tabel 5 menunjukkan bahwa angka beban ketergantungan dan angka harahapn hidup memberikan pengaruh positif signifikan terhadap GDP per kapita. Hasil tersebut dikonfirmasi dengan nilai probabilitas dan nilai koefisiennya. Pada variabel dependency age ratio terlihat bahwa nilai koefisien sebesar $-524,2462$ dan nilai probabilitas sebesar 0,0017 kurang darin nilai alfa $5 \%$. Ini berarti ketika terjadi penurunan angka beban ketergantungan justru meningkatkan GDP per kapita. Hasil sama ditunjukkan oleh variabel life expected yang menunjukkan angka probabilitas 0,0002 dan nilai koefisien sebesar 2171,857. Ini berarti bahwa ketika terjadi kenaikan angka harapan hidup ini akan meningkatkan GDP per kapita dalam jangka panjang.

Berdasarkan hasil analisis diatas dapat dilakukan diskusi lebih lanjut untuk memperdalam pembahasan tentang profil demografi dan pertumbuhan ekonomi Indonesia selama periode penelitian. Pada dasarnya Indonesia merupakan negara dengan jumlah penduduk tertinggi di ASEAN dan tertinggi ketiga di Asia setelah Tiongkok dan India. Ini menunjukkan bahwa jumlah penduduk yang tinggi diharapkan mampu memberikan kontribusi besar terhadap perekonomian Indonesia. Selama periode penelitian dalam kurun waktu 1980-2016 variabel demografi Indonesia belum mampu memberikan kontribusi positif terhadap perekonomian hingga mengakibatkan perlambatan ekonomi. Kondisi ini ditunjukkan pada hasil analisis jumlah angkatan kerja dan jumlah populasi Indonesia ternyata menyebabkan perlambatan ekonomi Indonesia. Hasil tersebut diperkuat dengan hasil estimasi profil demografi yang menunjukkan bahwa kenaikan jumlah angkatan kerja ternyata tidak mampu memberikan peningkatan GDP per kapita Indonesia akibat masih rendahnya tenaga kerja terdidik. Disisi lain, kemajuan teknologi yang belum mampu dijangkau secara masif oleh tenaga kerja Indonesia serta peralihan sektor utama dari sektor pertanian yang mulai bergeser pada sektor indusri. Hal ini dapat berdampak pada perekonomian sebab dapat menurunkan produktifitas dan pendapatan per kapita jika angkatan kerja tidak mampu bersaing optimal dengan adanya kemajuan teknologi yang terjadi.

Berbeda dengan hasil penelitian ini, bonus demografi yang berkaitan erat dengan transisi demografi seharusnya mampu memberikan kontribusi positif terhadap perekonomian. Sepeerti studi empiris yang dilakukan oleh Menike (2013) menunjukkan hasil bahwa bonus demografi pada negara negara besar Asia mampu memberikan kontribusi besar pada percepatan ekonomi negaranya. Hasil ini mengindikasikan perlunya kebijakan yang ketat terhadap pengendalian jumlah penduduk serta manajemen bonus demografi yang dapat memberikan kontribusi terhadap perekonomian Indonesia. Salah satu kebijakan yang dapat diterapkan berkaitan dengan peningkatan kualitas angkatan kerja Indonesia sehingga mampu berkolaborasi dengan kemajuan teknologi yang ada. Instrumen kebijakan yang dapat dilakukan misalnya dapat melalui kebijakan anggaran terkait dengan sektor pendidikan yang difokuskan pada peningkatan kualitas tenaga kerja.

Simulasi pada studi empiris yang dilakukan oleh Dissou, et al. (2012) yang menjelaskan bahwa dalam jangka panjang, government spending dapat meningkatkan modal fisik dan kualitas sumber data manusia mellaui transfer pemerintah untuk subsidi pendidikan dan pelatihan. Hal ini dapat menjadi referensi simulasi kebijakan pemerintah untuk melakukan peningkatan government spending pada sektor pendidikan baik pendidikan formal maupun informal. Selain itu, government spending juga dapat diarahkan pada 
pelatihan-pelatihan yang dapat diikuti oleh seluruh tenaga kerja yang memiliki keterbatasan keterampilan mengingat tenaga kerja Indonesia didominasi oleh tenaga kerja tidak terdidik.

Sementara itu, hasil berbeda ditunjukkan oleh variabel makroekonomi Indonesia yang diwakili oleh ekspor dan jumlah persebaran industri. Hasil analisis menunjukkan bahwa peningkatan ekspor akan mendorong percepatan pertumbuhan ekonomi Indonesia melalui GDP per kapita serta peningkatan jumlah industri juga mendorong percepatan perekonomian Indonesia. Peningkatan pertumbuhan ekonomi Indonesia yang didorong oleng peningkatan jumlah persebaran industri ini didominasi oleh keberadaan sektor manufaktur (Panggabean, 2016). Selain itu pada sisi ekspor menunjukkan kinerja yang positif signifikan meskipun hal ini tidak seimbang dengan penurunan impor akibat melemahnya perekonomian dunia serta depresiasi nilai rupiah pada 2015 (Bank Indonesia, 2015). Disisi lain, meskipun terjadi pelemahan nilai ekspor pada kurun waktu 2012 hingga 2016, namun pertumbuhan ekonomi Indonesia masih dalam kondisi kuat dan aman (OECD, 2016).

Hasil estimasi model kedua yang memaparkan hubungan antara profil demografi dengan pertumbuhan ekonomi melalui GDP per kapita Indonesia menunjukkan hasil yang mengejutkan. Kondisi ini ditunjukkan dengan pengaruh signifikan antara variabel dependency ratio yang berdampak positif terhadap perekonomian dalam jangka panjang yang dikonfirmasi pada hasil uji kointegrasi dan OLS. Hal ini mengindikasikan bahwa struktur persebaran penduduk berdasarkan umur di Indonesia didominasi oleh penduduk usia produktif sehingga angka beban ketergantungan dapat menurun yang akan berdampak pada peningkatan perekonomian. Berdasarkan laporan Bank Indonesia, Indonesia diperkirakan akan memperoleh bonus demografi kisaran tahun 20202030 mendatang sehingga akan berdampak pada dependency ratio yang semakin menurun (Departemen Statistik Ekonomi dan Moneter, 2011). Hasil ini mengindikasikan bahwa perlu adanya kebijakan yang harus dipersiapkan untuk menyambut bonus demografi tersebut agar dapat dimanfaatkan keberadaan secara optimal dalam meningkatkan perekonomian Indonesia. Selain itu, angka harapan hidup juga memberikan dampak positif terhadap pertumbuhan ekonomi Indonesia yang dikonfirmasi dengan hasil positif signifikan pada hasil estimasi. Semakin tinggi harapan hidup penduduk Indonesia terlebih pada penduduk usia produktif diharapkan mampu memberikan kontribusi pada perekonomian dan kesejahteraan.

Berdasarkan analisis dan diskusi diatas dapat disimulasikan kebijakan yang berfokus pada manajemen profil demografi terlebih pada peningkatan kualitas tenaga kerja agar dapat mencapai kontribusi positif dalam mendorong perekonomian Indonesia. Selain itu juga kontrol pada laju pertumbuhan penduduk juga harus ditekankan agar bonus demografi yang diproyeksikan dapat tercapai pada tahun 2020-2030 dapat berjalan dengan baik dan optimal.

\section{KESIMPULAN DAN REKOMENDASI}

Penelitian ini memberikan kesimpulan bahwa dalam periode penelitian selama kurun waktu 1980-2016 menunjukkan bahwa bonus demografi menjadi penyebab perlambatan ekonomi Indonesia. Sementara itu, ekspor dan sebaran industri ternyata mampu menunjukkan kontribusi positif bagi perekonomian Indonesia. Hasil lain menunjukkan bahwa dalam profil demografi Indonesia yang disimulasikan dapat berkontribusi mendorong pendapatan per kapita melalui GDP per kapita menunjukkan hasil yang berbeda. Hasil ini dikonfirmasi dengan kontribusi positif dari variabel dependency ratio dan life expec- 
tacy terdahadap GDP per kapita dalam jangka panjang. Hasil ini sesuai dengan proyeksi beberapa ahli yang menginformasikan bahwa bonus demografi Indonesia akan tercapat dalam periode 2020-2030 mendatang.

Dari hasil tersebut, rekomendasi kebijakan yang dapat disarankan pada penelitian ini difokuskan pada manajemen sumber daya manusia terlebih pada peningkatan kualitas sumber daya manusia agar dapat berkolaborasi secara optimal dengan kemajuan teknologi dan dipersiapkan dalam menyambut bonus demografi 2 tahun mendatang.

\section{DAFTAR PUSTAKA}

ADB. (2016). Asia'S Potential Growth Outlook 2016.

Aiyar, S and A Mody (2011) The demographic dividend: Evidence from the Indian states. IMF Working Paper 11/38 (IMF, NewYork); www.imf.org/external/pubs/ ft/wp/2011/wp1138.pdf.

Aiyar, S., Romain A. Duval, Damien Puy, Yiqun Wu and Longmei Zhang. (2013). Growth Slowdowns and the MiddleIncome Trap. IMF Working Papers No. 13/71 International Monetary Fund

Bank Indonesia. (2015). 2015 Economic Report on Indonesia. ISSN 0522-2572.

Bloom, David E and JGWilliamson. (1998). Demographic Transitions and Economic Miracles in Emerging Asia. Perspective World economic Bank Economic Review,12 (3): 419-56

Craven, B. D., \& Islam, S. M. N. (2011). Ordinary Least Squares Regression. The SAGE Dictionary of Quantitative Management Research, 224-228. https:// doi.org/10.4135/9781446251119.n67

Direktorat Statistik dan Moneter. (2011). Informasi Kependudukan Indonesia, (November).
Dissou, Y., Didic, S., \& Yakautsava, T. (2012). Government Spending on Education, Human Capital Accumulation, and Growth*, (June).

Drehmann, M., Sorensen, S., \& Stringa, M. (2006). Integrating credit and interest rate risk : A Theoretical Framework and an Application to Banks â€TM Balance Sheets.

Eichengreen, Barry, Dwight Perkins and Kwanho Shin. (2013). Growth Slowdowns Redux: New Evidence on the Middle Income Trap. NBER Working Paper No. 18673

Fang, C., \& Wang, D. (2000). Demographic Transition : Implications For Growth, 34-52.

Galo Nuno, Cristina Pulido, and Ru. S. C. (2012). Long-run Growth and Demographic Pospects in Advanced Economies.

Greene, William H. (2012). Econometric Analysis Sevent Edition. New York: Prentice Hall

Hasoloan, Maruli A. _. Country Report The Indonesian Labor Market. The OECD Forum on the Restated OECD Jobs Strategy

Hausmann, Ricardo and C. Hidalgo. (2010). Country Diversification, Product Ubiquity, and Economic Divergence. CID Working Paper No. Harvard University.

Hjalmarsson, E., \& Österholm, P. (2010). Testing for cointegration using the Johansen methodology when variables are near-integrated: Size distortions and partial remedies. Empirical Economics, 39(1), 51-76. https://doi.org/10.1007/ s00181-009-0294-6

Irfani Fithria dkk. (2015). Perekonomian Indonesia Di Tengah Bayang-Bayang Perlambatan Global. RPM FEUI Quarterly Report, 3. Retrieved from 
http://www.feb.ui.ac.id/wp-content/ uploads/2014/12/RPM-FEUI-QuarterlyReport-2015-Vol.-3.pdf

Jayasooriya, S. P. (2017). Growth Slowdowns, Middle Income Trap, and Demographic Profile in South Asia, (736).

Joe, W., Dash, A. K., \& Agrawal, P. (2015). Demographic Transition, Savings, and Economic Growth in China and India. IEG Working Paper, (351).

Jorgensen, O. H. (2010). Health, Demographic Transition and Economic Growth. World, (May).

Lehmijoki, U. (2003). Demographic Transition and Economic Growth (Vol. 8).

Mason, A. (2005). Demographic Transition and Demographic Dividends in Developed and Developing Countries. The Extraordinary General Meeting (EGM), p.22. https://doi.org/10.1017/ CBO9781107415324.004

Mencet, M. N., \& Firat, M. Z. (2006). Cointegration analysis of wine export prices for France, Greece and Turkey. Exchange Organizational Behavior Teaching Journal, 1-17.

Misra, R. (2015). Impact of Demographic Dividend on Economic Growth. International Studies, 52(1-4), 99-117. https:// doi.org/10.1177/0020881717714685

OECD. (2016). Survei Ekonomi OECD INDONESIA, 4. Retrieved from https://www.oecd.org/eco/surveys/ indonesia-2016-OECD-economicsurvey-overview-bahasa.pdf

Panggabean, A. (2017). Economic outlook: Indonesia in 2017, (November 2016).

Peterson, E. W. F. (2017). The Role of Population in Economic Growth. SAGE Open, 7(4). https://doi. org/10.1177/2158244017736094

Robertson, Peter and Longfeng Ye. (2013). On The Existence Of a Middle Income
Trap. Economic Discussion Paper No: 13-12. University of Western Australia, Perth.

Rynn, J. (2001). Theories of Rise and Fall, Part 2: Neoclassical Economic Growth Theory. The Power to Create Wealth: A Systems-Based Theory of the Rise and Decline of the Great Powers in the 20th Century, 62-85.

Williamson, Jeffrey. (1997). Growth, Distribution and Demography: Some Lessons From History. NBER Working No.6244, National Bureau Economic Research, Cambridge, MA. World 